\title{
Nuclear energy and Anthropocene
}

\author{
Ettore Fiorini
}

Received: 23 April 2013/Accepted: 5 July 2013/Published online: 15 October 2013

(C) The Author(s) 2013. This article is published with open access at Springerlink.com

\begin{abstract}
After a short introduction on the basic physical problems of the application of nuclear physics to unfortunate military scopes and to civil production of nuclear energy we will consider their relatively recent and possible important impact on Anthropocene. Special emphasis will be devoted to the present continuous production of nuclear wastes and to their disposal, particularly in deep storage locations.
\end{abstract}

Keywords Nuclear energy $\cdot$ Nuclear wastes $\cdot$ Disposal · Deep storage

\section{Introduction}

The effects of nuclear energy in Anthropocene are relatively recent and can be due in principle both to fission and fusion. The military application of nuclear fission led about seven decades ago to the nuclear test in New Mexico followed by the tragic events of Hiroshima and Nagasaki. From then the application of fission and fusion to nuclear tests produced considerable and sometimes hidden effects in the environment. Since about six decades interest was also addressed to the civil production of nuclear energy which has now reached a considerable percentage in the energy balance of many

This contribution is the written, peer-reviewed version of a paper presented at the conference "Anthropocene-Natural and man-made alterations of the Earth's fragile equilibrium", held at Accademia Nazionale dei Lincei in Rome on November 26-27, 2012.

E. Fiorini $(\square)$

Dipartimento di Fisica and INFN, Università di Milano-Bicocca,

Piazza della Scienza 3, 20126 Milan, Italy

e-mail: ettore.fiorini@mib.infn.it

E. Fiorini

Accademia Nazionale dei Lincei, Rome, Italy countries. This has been accomplished so far only by fission, and the hopes of civil production by fusion have been so far frustrated. We will therefore be concerned here only to the former of these processes.

The potentiality to produce nuclear energy can be easily understood by inspecting Fig. 1 where the binding energy of a nucleus is divided by its atomic number A. It can be seen that the most stable nuclei present a maximum mean binding energy when $A$ is around 60. As a consequence energy can be obtained either by splitting heavy nuclei like ${ }^{235} \mathrm{U}$ (fission) or unite light ones (fusion).

\section{Nuclear fission}

Civil nuclear energy by fission is mainly produced by capture on ${ }^{235} \mathrm{U}$ of thermal neutrons with a very low energy (about $0.025 \mathrm{eV}$ ).

$\mathbf{n}_{\text {thermal }}=>{ }^{235} \mathbf{U}+\mathbf{X}+\mathbf{Z}+m \mathbf{n}_{\text {fast }}$

where $\mathbf{X}$ and $\mathbf{Z}$ are fission fragments and the number $m$ of generated neutrons is in average of 2.47. The energy of these neutrons is, however, too large to produce further fissions and has to be reduced by means of a suitable moderator (Carbon, $\mathrm{H}_{2} \mathrm{O}, \mathrm{D}_{2} \mathrm{O}$ etc.). Moderated neutrons can then produce further fissions and give rise to the chain reaction shown in Fig. 2.

The role played by Uranium isotopes in nuclear fission is reported in Table 1. The captured thermal neutron delivers to the nucleus an excitation energy which should be larger than the activation energy needed to produce fission. Only the 233 and 235 isotopes of Uranium obey this rule, with isotopic abundances of 0.005 and $0.72 \%$, respectively. The abundance of the former is too low for its use in a reactor, unless produced in other ways, while the one of ${ }^{235} \mathrm{U}$ can be sufficient in some reactor, like the first one built by Fermi, but it 
Fig. 1 Mean binding energy as a function of atomic number

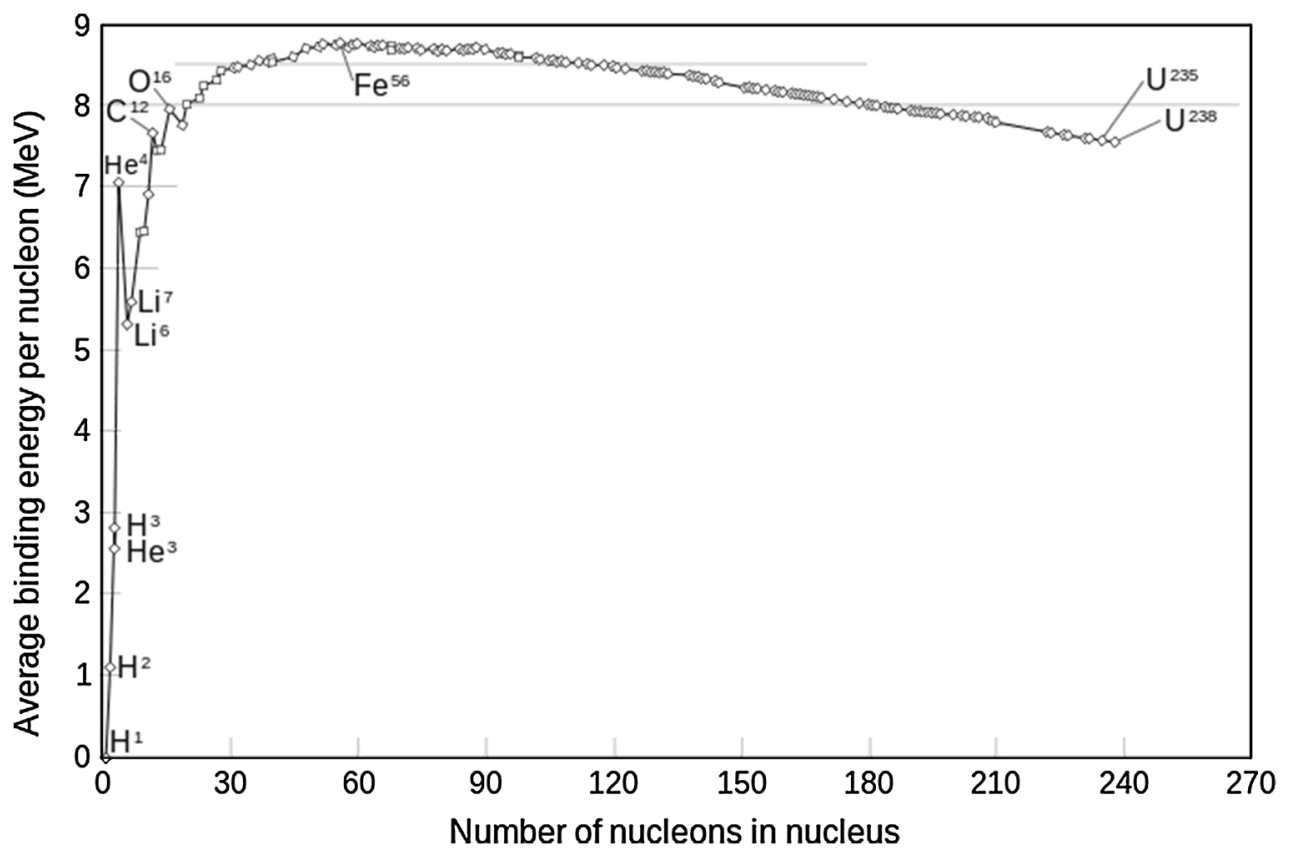

Fig. 2 Scheme of nuclear fission chain
Table 1 Properties of some relevant isotopes

\begin{tabular}{llll}
\hline Nucleus & Binding energy & Activation energy & $\sigma$ (barn) \\
\hline${ }^{232} \mathrm{Th}$ & 4.8 & 6.7 & $<10^{-6}$ \\
${ }^{233} \mathrm{U}$ & 6.8 & 5.85 & 531.8 \\
${ }^{235} \mathrm{U}$ & 6.5 & 5.9 & 579 \\
${ }^{238} \mathrm{U}$ & 4.8 & 5.8 & $2.7 \times 10^{-6}$ \\
${ }^{239} \mathrm{Pu}$ & 6.5 & 6.3 & 742 \\
\hline
\end{tabular}

incident neutron +

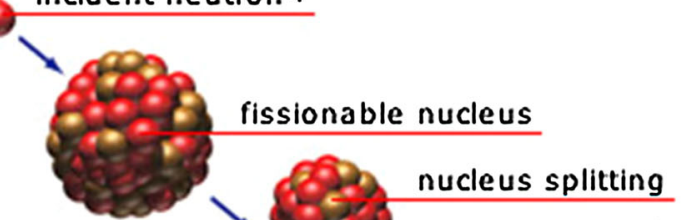

fission products (radioactive nuclei)

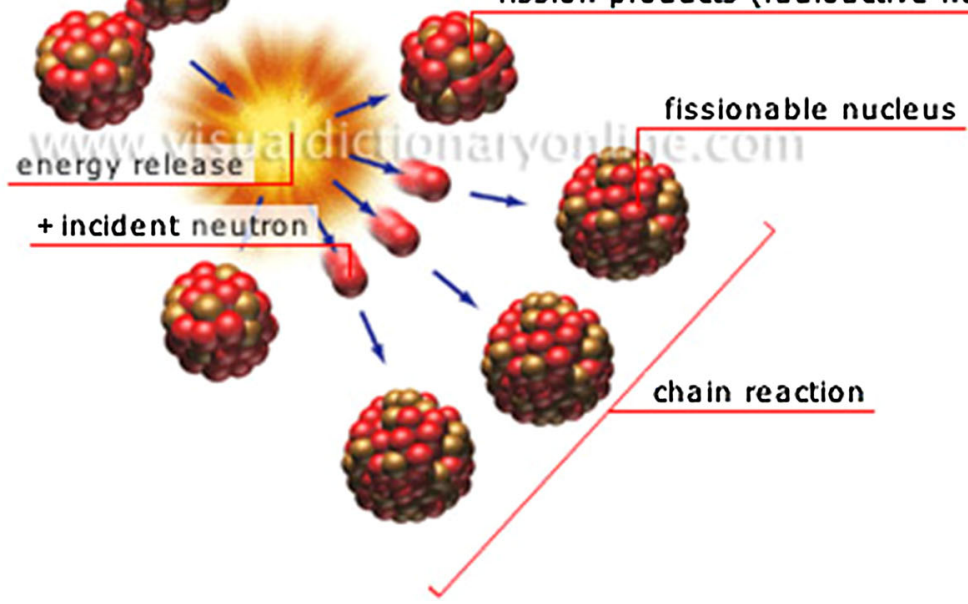

has to be enriched in most of the power reactors presently running. One can note the attractive properties of the artificial isotope ${ }^{239} \mathrm{Pu}$ which we will consider later.

\section{Nuclear wastes}

The main problem and challenge in the present and especially in the future civil and unfortunately military 
Fig. 3 Proton versus neutron number. Stable nuclei are shown in black

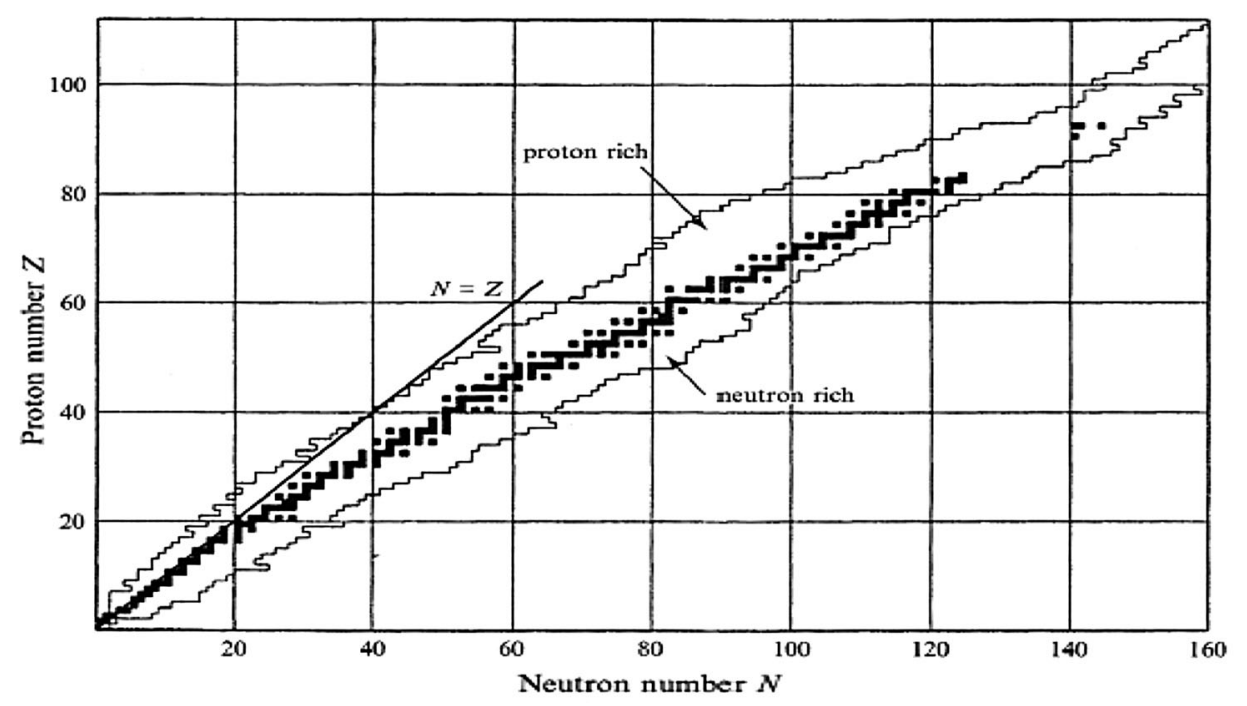

development of nuclear energy stays in the unavoidable production of radioactive isotopes: the so called nuclear wastes. In heavy nuclei, the presence of neutrons with respect to protons has to be larger to keep them together, overcoming the larger coulomb repulsion (Fig. 3). This is less true for fission fragments much richer in neutrons and therefore unstable. They are below the line of the stable nuclei evidenced in the figure and tend to stability with a chain of beta decays of generally increasing half lifetime.

The presence of these isotopes of both civil and military origin adds to the natural radioactive environment as shown in Fig. 4. Present environmental radioactivity is in fact due to.

1. Fossil radioactivity from pre-existing atoms like Uranium, Thorium or Potassium
2. Cosmogenic radioactivity due to activation by interactions of Cosmic Rays

3. Anthropogenic radioactivity due to isotopes produced mainly by nuclear explosion or tests, by the production of nuclear energy or even of radioisotopes for medical and/or other civil applications

\section{Nuclear reactors}

A draft of the first nuclear reactor constructed by Fermi in the swimming pool of the University of Chicago and secretly sketched against the strict military secrecy laws is shown in Fig. 5. We would like to stress that the scope of this reactor was not the production of energy, but just to prove the possibility to produce a chain reaction for
Fig. 4 Present gamma spectrum of the sum of fossil, cosmogenic and anthropogenic radioactivity

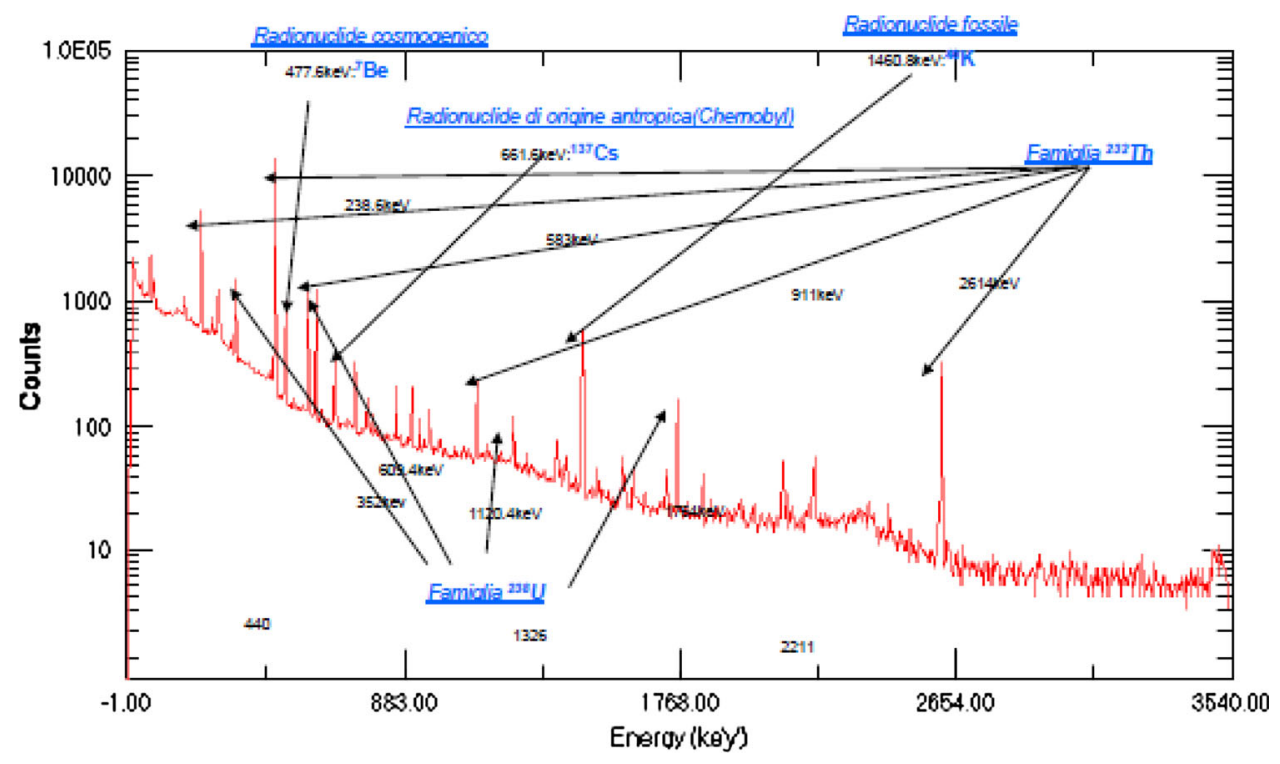




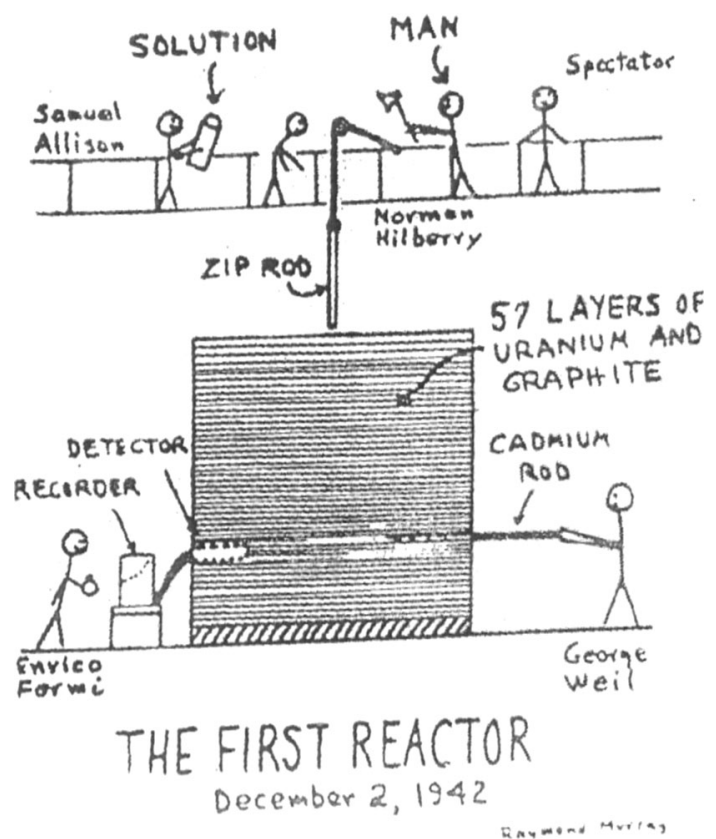

Fig. 5 The first reactor

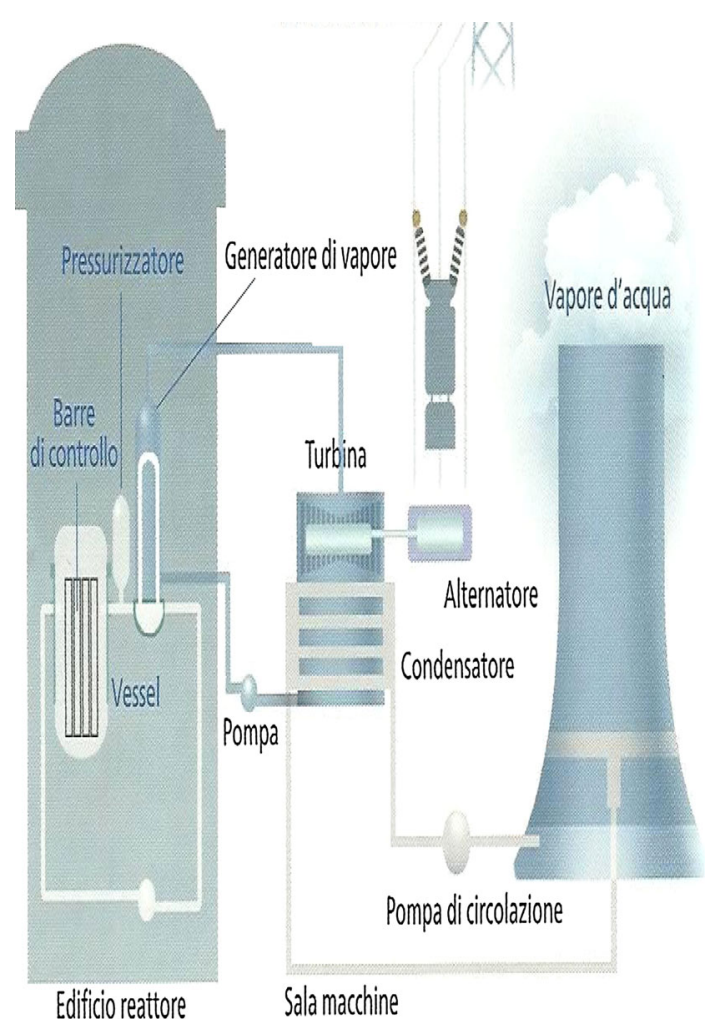

Fig. 6 A present power reactor

military purpose. This brought to the nuclear military era with great efforts for the development and test of nuclear weapons. It was only with the sixties that interest was devoted to reactors specifically constructed for the production of energy (Fig. 6).

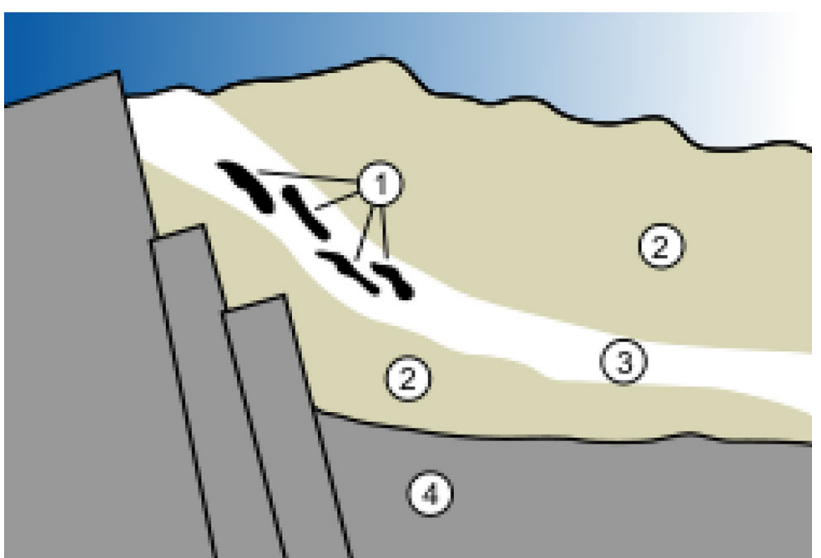

Fig. 7 The Oklo 1 reactor: 1 Nuclear reactor zones. 2 Sandstone. 3 Uranium ore layer. 4 Granite

It could be of some interest for geologists that nuclear reactors existed in Nature! In present reactors the natural abundance of ${ }^{235} \mathrm{U}(0.72 \%)$ has to be increased by about three times to allow the chain fission reaction to occur in a reactor, but a moderator has to be present. Billions years ago ${ }^{235} \mathrm{U}$ and ${ }^{238} \mathrm{U}$ existed with the same amount, but the abundance of ${ }^{235} \mathrm{U}$ decreased more rapidly than for ${ }^{238} \mathrm{U}$ due to the lower half lifetime (0.704 instead than 4.47 Gigayears). In geological times the ratio between isotopes 235 and 238 was therefore much larger than the present one, but a chain fission could only occur in presence of a suitable moderator. In some case, however, water was present. A known and proved case was the Oklo reactor in the African region of Gabon shown in Fig. 7 where apparently a moderator like water or granite was present. The occurrence of this reactor about 1.7 Gigayears ago was geological suggested, but later also proved by specific measurements which revealed a geologically abnormal lack of ${ }^{235} \mathrm{U}$ and the presence of isotopes which could only be produced by a chain reaction. (Curtin University 2012).

Two major disasters due to nuclear reactors took place so far: one in 1987 in Chernobyl (then USSR) and recently in Fukushima (Japan).

The effect on environmental radioactivity by the Chernobyl accident in Milan is shown by our gamma ray spectrum of Fig. 8 recorded then. One can notice the presence of the radioactive isotopes of Iodine, Ruthenium and Cesium in addition to the lines due to natural radioactivity. We would like to note that, due to its relatively long lifetime (30.07 years), a minor contribution from ${ }^{137} \mathrm{Cs}$ due to the Chernobyl accident is still present in air particulate in Italy.

Despite the much larger distance from Fukushima we were able to detect recently the contamination of the isotopes of Cesium and Iodine (Clemenza et al. 2012) as shown in Fig. 9. 
Fig. 8 Additional environmental radioactivity due to the Chernobyl incident in 1986

Fig. 9 Evidence in Milan particulate of the effects of the Fukushima incident
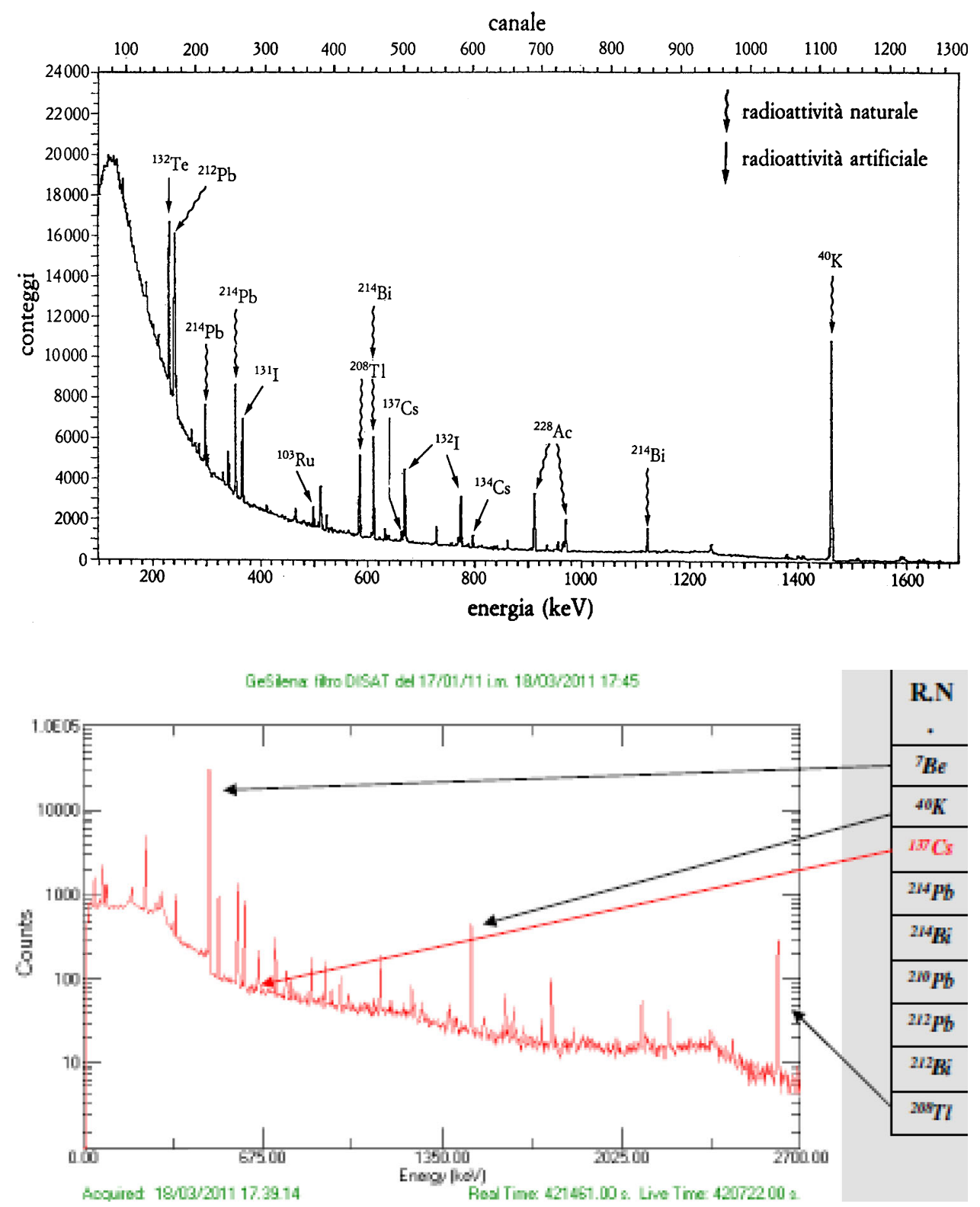

\section{Disposal of nuclear wastes}

Nuclear wastes come from various sources: military and civil reactors, nuclear tests and pacific application of nuclear physics (medical, agricultural, industry). We will not be concerned here with the third, since it is negligible with respect to the first two. A great amount of wastes were produced at the beginning of the nuclear era especially in USA and in USSR for their competition in the production of atomic bombs. In particular the dangerous plutonium was produced also as a reactor fuel in the worry of lack of Uranium. Further wastes were and are continuously generated for civil production of energy by the large number (almost 500) of operating power reactors. The concern is obviously related to the future destiny of nuclear energy and depends on the quantity and lifetime of the produced radioactive isotopes. We can roughly classify these radioactive nuclei according to their lifetime as shown in Table 2.

The general classification of nuclear wastes is unfortunately controversial and different among the various nuclear countries (Sook Jung et al. 2012). According to the International Atomic Energy Agency (IAEA) wastes can be classified as following:

1. High-level wastes (HLW): wastes containing larger concentrations of both short- and long-lived radionuclides than ILW and generally having an activity concentration of $10^{4}-10^{6} \mathrm{~Bq} / \mathrm{g}$ 
Table 2 Classification of nuclear wastes according to their lifetime

\begin{tabular}{|c|c|}
\hline Lifetime & Fission products \\
\hline 1-10 days & $\begin{array}{l}{ }^{72} \mathrm{Zn},{ }^{67} \mathrm{Ga},{ }^{77} \mathrm{As},{ }^{82} \mathrm{Br},{ }^{90} \mathrm{Y},{ }^{95} \mathrm{Nb},{ }^{99} \mathrm{Mo},{ }^{103} \mathrm{Rh},{ }^{105} \mathrm{Rh},{ }^{109} \mathrm{Ag},{ }^{115} \mathrm{Cd},{ }^{115} \mathrm{I},{ }^{127} \mathrm{Sb},{ }^{131} \mathrm{Te},{ }^{131} \mathrm{I},{ }^{132} \mathrm{Te},{ }^{129} \mathrm{Xe}, \\
{ }^{135} \mathrm{Xe},{ }^{135} \mathrm{Xe},{ }^{135} \mathrm{Ba},{ }^{140} \mathrm{La},{ }^{143} \mathrm{Ce},{ }^{147} \mathrm{Pm},{ }^{14} \mathrm{Pm},{ }^{151} \mathrm{Eu},{ }^{153} \mathrm{Eu},{ }^{155} \mathrm{Eu},{ }^{161} \mathrm{Gd},{ }^{161} \mathrm{~Tb},{ }^{166} \mathrm{Dy},{ }^{166} \mathrm{Ho}\end{array}$ \\
\hline 10-100 days & $\begin{array}{l}{ }^{86} \mathrm{Ru},{ }^{89} \mathrm{Sr},{ }^{91} \mathrm{Y},{ }^{95} \mathrm{Zr},{ }^{95} \mathrm{Nb},{ }^{131} \mathrm{Ru},{ }^{115} \mathrm{Cd},{ }^{117} \mathrm{Sn},{ }^{134} \mathrm{Sb},{ }^{126} \mathrm{Sb},{ }^{125} \mathrm{Te},{ }^{139} \mathrm{Te},{ }^{131} \mathrm{Xe},{ }^{131} \mathrm{Cs},{ }^{143} \mathrm{Pr},{ }^{147} \mathrm{Nd},{ }^{151} \mathrm{Pmk},{ }^{156} \mathrm{Eu},{ }^{131} \mathrm{Te} \text {, }\end{array}$ \\
\hline $\begin{array}{l}100 \text { days- } \\
10 \text { years }\end{array}$ & ${ }^{119} \mathrm{Sn},{ }^{123} \mathrm{Sn},{ }^{121} \mathrm{Te},{ }^{127} \mathrm{Te},{ }^{134} \mathrm{Cs},{ }^{144} \mathrm{Ce},{ }^{147} \mathrm{Pm},{ }^{154} \mathrm{Eu},{ }^{135} \mathrm{Eu},{ }^{151} \mathrm{Sm}$ \\
\hline $\begin{array}{l}10^{-5} \times 10^{8} \text { years } \\
>5 \times 10^{8} \text { years }\end{array}$ & $\begin{array}{l}{ }^{85} \mathrm{Kr},{ }^{90} \mathrm{Sr},{ }^{93} \mathrm{Zr},{ }^{93} \mathrm{Nb},{ }^{99} \mathrm{Tc},{ }^{107} \mathrm{Pd},{ }^{107} \mathrm{Cd},{ }^{107} \mathrm{Ag},{ }^{121} \mathrm{Sn},{ }^{126} \mathrm{Sn},{ }^{129} \mathrm{I},{ }^{135} \mathrm{Cs},{ }^{137} \mathrm{Cs},{ }^{131} \mathrm{Te}, \\
{ }^{82} \mathrm{Se},{ }^{87} \mathrm{Ru},{ }^{116} \mathrm{Cd},{ }^{130} \mathrm{Te},{ }^{114} \mathrm{Nd},{ }^{147} \mathrm{Sm},{ }^{152} \mathrm{Gd},\end{array}$ \\
\hline
\end{tabular}

2. Intermediate level wastes (ILW): wastes requiring a greater degree of containment and isolation than that of nearer surface disposal

3. Low level wastes (LLW): these wastes are suitable for near surface disposal. They generally have a limit of $400 \mathrm{~Bq} / \mathrm{g}$ on average $(4,000 \mathrm{~Bq} / \mathrm{g}$ for individual packages) for longer lived alpha emitting radionuclides

In a simplified approach two categories can be considered from the storage point of view:

1. Low level materials to handle strongly radioactive parts of reactors (e.g., cooling liquid, contaminated parts), radioactive sources even from nuclear medicine, industry etc., with limited lifetimes to be disposed for tens of years in pools or concrete structures

2. Actinides (in particular Plutonium) produced during fission, to be stored for geological time or reprocessed

One way to solve the problem of nuclear wastes is to limit their production with new types of reactors, or to reduce the produced ones by partitioning and transmutation (Ojovan and Lee 2005; Sook Jung et al. 2012). The former process consists in separating out of the spent fuel the radiotoxic components, the latter is based on recycling them in a way to minimize their toxicity and recover their contained energy in a useful way. We note that one or the Fukushima reactors was charged also with Plutonium. This nuclear reprocessing reduces the volume and the long-term radiation hazard and heat dissipation capacity needed. Reprocessing does not, however, eliminate the political and community challenges and require the need for the repository of nuclear wastes where they can be safely insulated from the biosphere for at least hundred thousand years (Pusch 1994; Ojovan and Lee 2005; Pusch 2008). We will be concerned here with the deep storage for geological times, because it can be closely connected with Anthropocene.

In USA, a country heavily involved since the beginning, like USSR, in the military applications of nuclear age many equipments were contaminated with amounts of radioactivity. This was mainly due to the production of nuclear weapons during WWII and the Cold War. They have been shipped to WIPP (Waste Isolation Pilot Plant) where the contaminants are permanently isolated and stored. This site is used even now to store nuclear wastes, but it is presently inadequate for the large amount of continuously produced radioactive material.

Many hopes were addressed in USA on the so called Yucca project (Fig. 10) initiated in 1978 for a long-term geological depository for spent nuclear fuel and high-level radioactive wastes. Recently, however, after animated litigation between the local agency for Nuclear Project of the State of Nevada and the Obama Administration the Yucca Project has been definitely canceled (New York Times 2011, May 9). This leaves United States civilians without

Fig. 10 The proposed Yucca site

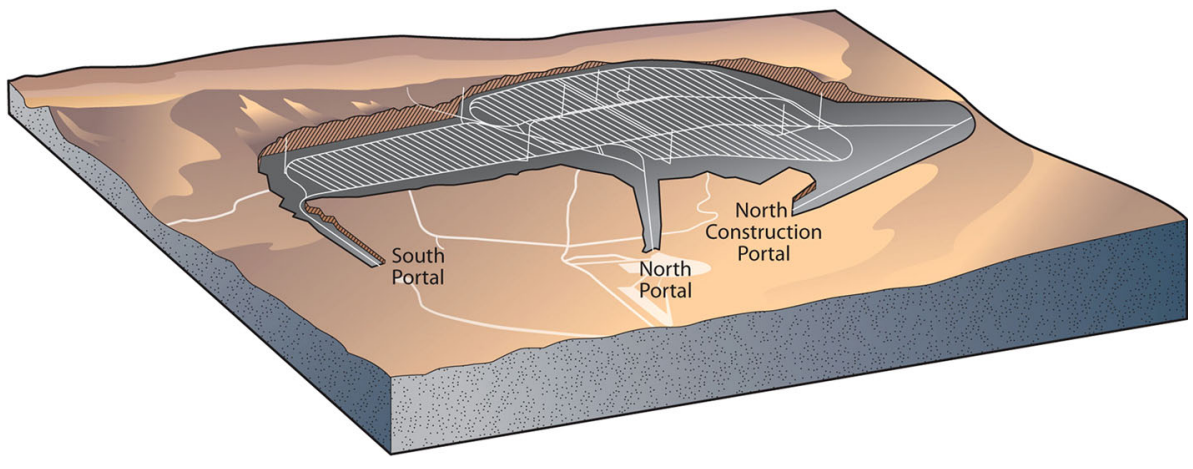


Table 3 Presently studied sites for disposal of nuclear wastes

\begin{tabular}{|c|c|c|c|c|c|c|}
\hline Country & Facility name & Location & Waste & Geology & Depth & Status \\
\hline Argentina & Sierra del Medio & Gastre & & Granite & & Under discussion \\
\hline Belgium & & & High-level waste & Plastic clay & $\sim 225 \mathrm{~m}$ & Under discussion \\
\hline Canada & OPG DGR & Ontario & $\begin{array}{l}200,000 \mathrm{~m}^{3} \\
\text { L\&ILW }\end{array}$ & $\begin{array}{l}\text { Argillaceous } \\
\text { limestone }\end{array}$ & $680 \mathrm{~m}$ & Licence application 2011 \\
\hline Canada & & & Spent fuel & & & Under discussion \\
\hline China & & & & & & Under discussion \\
\hline Finland & VLJ & Olkiluoto & L\&ILW & Tonalite & $60-100 \mathrm{~m}$ & In operation 1992 \\
\hline Finland & & Loviisa & L\&ILW & Granite & $120 \mathrm{~m}$ & In operation 1998 \\
\hline Finland & Onkalo & Olkiluoto & Spent fuel & Granite & $400 \mathrm{~m}$ & Under construction \\
\hline France & & & High-level waste & Mudstone & $\sim 500 \mathrm{~m}$ & Siting \\
\hline Germany & Schacht Asse II & $\begin{array}{l}\text { Lower } \\
\text { Saxony }\end{array}$ & & Salt dome & $750 \mathrm{~m}$ & Closed 1995 \\
\hline Germany & Morsleben & $\begin{array}{l}\text { Saxony- } \\
\text { Anhalt }\end{array}$ & $\begin{array}{c}40,000 \mathrm{~m}^{3} \\
\text { L\&ILW }\end{array}$ & Salt dome & $630 \mathrm{~m}$ & Closed 1998 \\
\hline Germany & Gorleben & $\begin{array}{l}\text { Lower } \\
\text { Saxony }\end{array}$ & High-level waste & Salt dome & & Proposed, on hold \\
\hline Germany & Schacht Konrad & $\begin{array}{l}\text { Lower } \\
\text { Saxony }\end{array}$ & $\begin{array}{l}303,000 \mathrm{~m}^{3} \\
\text { L\&ILW }\end{array}$ & Sedimentary rock & $800 \mathrm{~m}$ & Under construction \\
\hline Japan & & & High-level waste & & & Under discussion \\
\hline Korea & Gyeongju & & L\&ILW & & $80 \mathrm{~m}$ & Under construction \\
\hline Sweden & SFR & Forsmark & $\begin{array}{c}63,000 \mathrm{~m}^{3} \\
\text { L\&ILW }\end{array}$ & Granite & $50 \mathrm{~m}$ & In operation 1988 \\
\hline Sweden & & Forsmark & Spent fuel & Granite & $450 \mathrm{~m}$ & Licence application 2011 \\
\hline Switzerland & & & High-level waste & Clay & & Siting \\
\hline $\begin{array}{l}\text { United } \\
\text { Kingdom }\end{array}$ & & & High-level waste & & & Under discussion \\
\hline USA & $\begin{array}{l}\text { Waste Isolation Pilot } \\
\text { Plant }\end{array}$ & New Mexico & Transuranic waste & Salt bed & $655 \mathrm{~m}$ & In operation 1999 \\
\hline USA & Yucca Mountain Project & Nevada & 70,000 ton HLW & Ignimbrite & $200-300 \mathrm{~m}$ & Proposed, canceled 2010 \\
\hline
\end{tabular}

any long-term storage site for high-level radioactive waste apart WIPP.

Deep geologic disposal has been and is being studied by practically all nuclear countries since several decades, including laboratory tests, as shown by Table 3 (Wikipedia 2012). The need for safe disposal of high-level nuclear waste (HLW) has been in focus of the International Atomic Energy Agency and of a number of national authorities for decades. Various concepts have been proposed for deep deposition in salt, argillaceous and crystalline rock, but no large repository has yet been constructed. Many countries outside USA that focus on disposal of nuclear wastes are interested in the design developed by the Swedish Nuclear Fuel and Waste Company based on tunnels at about $400 \mathrm{~m}$ depth with largediameter extending vertically from the tunnel. The plan is to place the waste in shallow places for tens of years after extraction to reduce radioactivity and the consequence release of heat and then to encapsulate them in a 400-500 deep repository in rock (Pusch and Weston 2012).

\section{Conclusions}

The future of the production of energy of nuclear origin is the object of animated economical, political, environmental and even ethical discussions. There is no doubt, however, that the major problem, despite in some way the future destiny of nuclear energy, is the need to dispose nuclear wastes. Even if new types of reactors capable to 'burn' or reduce future wastes, the already existing, and most likely the future ones will require their disposal in deep cavities to avoid any contact with the biosphere.

On the other side excavation of a large and suitable deep cavern to house nuclear wastes presents great difficulties from the mechanical, environmental, geological, financial and even psychological point of views. The unexpected, at least for me, failure of the Yucca project is a clear example.

The efforts to investigate this problem and especially to find suitable solution are at present in my opinion insufficient and require a further increased collaboration of 
geophysics with physics and other fields of science. This is the message of nuclear energy to Anthropocene.

Open Access This article is distributed under the terms of the Creative Commons Attribution License which permits any use, distribution, and reproduction in any medium, provided the original author(s) and the source are credited.

\section{References}

Clemenza M, Fiorini E, Previtali E, Sala E (2012) Measurement of airborne ${ }^{131} \mathrm{I},{ }^{134} \mathrm{C}$, and ${ }^{137} \mathrm{Cs}$ due to the Fukushima reactors incident in Milan (Italy). J Environ Radioact 114:113-118

Curtin University (2012) Report on the Oklo fossil nuclear reactor. http://oklo.curtin.edu.au/
New York Times (2011) GAO: Death of Yucca Mountain caused by political maneuvering

Ojovan MI, Lee WE (2005) An introduction to nuclear waste immobilisation. Elsevier Science Publishers, Amsterdam. 315, and references therein

Pusch R (1994) Waste disposal in rock, Dev Geotech Eng, Elsevier Publisher Co. 76, 7 and references therein

Pusch R (2008), Geological storage of radioactive waste, 978-3-54077332- Springer, Berlin, also for previous references]

Pusch R, Weston R (2012) Superior techniques for disposal of highly radioactive waste (HLW). Prog Nucl Energy 59:75-85

Sook Jung H, Sungyeol C, Soon Hwang I, Song M-J (2012) Environmental assessment of advanced partitioning, transmutation, and disposal based on long-term risk-informed regulation: PyroGreen. Prog Nucl Energy 58:27-38

Wikipedia (2012) Deep Geological Repository 